UDC: 576.321 .36

\title{
EFFECT OF AGMATINE ON ACTIN POLYMERIZATION IN LEUKOCYTES OF STREPTOZOTOCIN-INDUCED DIABETIC RATS
}

\author{
I. V. Brodyak, I. I. Bila, M. Overchuk, N. O. Sybirna \\ Ivan Franko National University of Lviv, 4, Hrushevskyi St., Lviv 79005, Ukraine \\ e-mail: sybirna_natalia@yahoo.com
}

It has been shown that agmatine affects the process of actin polymerization in leukocytes from both healthy rats and rats with experimentally induced diabetes mellitus (EDM). Our studies revealed that the initial general F-actin level in the leukocytes of diabetic rats was substantially higher than in the leukocytes of the healthy animals. This implies that leukocytes undergo a number of structural and functional changes and are in pre-activated state at the diabetes mellitus conditions. While the total actin content in the leukocytes of EDM rats dropped, we observed a redistribution of actin fractions, namely the level of cytoskeletal actin filaments decreased, whereas the abundunce of short actin filaments increased. Thus, actin polymerization intensifies in EDM conditions, although the initial actin content decreases. Agmatine administration to the control group of animals didn't lead to significant changes in general actin content in leukocytes, while the level of actin monomers decreased due to polymerization and short actin filaments formation. Treatment of the diabetic rats with agmatine resulted in elevated content of both general actin and cytoskeletal actin filaments as a result of reorganization of short actin filaments. Our data suggest that this polyamine directly or indirectly affects the functional state of leukocytes via altered cytoskeleton formation.

Keywords: actin, cytoskeleton, leukocytes, agmatine, experimental diabetes mellitus.

\section{INTRODUCTION}

Diabetes mellitus (DM) is a disease characterized by a number of metabolic disorders of multifactorial etiology [14]. Clinical and experimental assays have demonstrated that immunocompetent blood cells undergo severe morphofunctional changes in individuals with diabetes mellitus or in animals with streptozotocin-induced diabetes. Decreased chemotactic and phagocytic leukocyte activity associated with sustained hyperglycemia makes infections a frequent and severe systemic complications of diabetes mellitus [3, 25].

The pathogenesis of blood cell dysfunction in type $1 \mathrm{DM}$ is rather complicated and poorly studied. Micro- and macroangiopathies, which develop under DM conditions, together with accelerated progression of atherosclerosis, are accompanied by dysfunction of blood circulation, increased risk of thrombosis and can be a cause of sudden death. 
The most important functional changes that lead to angiopathies are the increase in vessel wall penetration, hemodynamic disorders, changes in blood viscosity and dysfunction of adhesive, aggregative and migrative abilities of leukocytes. These changes are typical for a certain morphofunctional state of leukocytes [16, 32, 36].

The functional state of leukocytes depends on the occurrence of complex interactions among membrane proteins, cytoskeleton, and signaling networks. Membrane/cytoskeleton association plays a key role in the maintenance of a dynamic cell shape and the continuous re-modeling of immune cell "signaling architecture." The ultimate reflection of this dynamic interaction is cellular polarization with the formation of distinct morphological and functional poles with an unidirectional orientation of leukocyte movement $[4,13]$. Actin cytoskeleton reorganization plays a crucial role in leukocyte locomotion; actin polymerization and depolymerization ensures migration ability of leukocytes [27, 10 ]. Leukocytes become activated once stimulated and fast polymerization of G-actin monomers occurs [9]. Actin dimers and trimers are unstable, therefore, to proceed toward the generation of new actin filaments, they must associate with nucleation-promoting factors. Actin polymerization requires free barbed ends. They can arise by nucleation of new actin filaments, by uncapping barbed ends in existing actin filaments through release of capping proteins, or by severing of noncovalent bonds between actin monomers within filamentous actin, resulting in shorter filaments with free barbed ends $[11,12,32]$. As lamellipodia move very fast (up to $1 \mathrm{~mm} / \mathrm{s}$ ), hundreds of actin subunits per second have to be detached from actin filaments at the negative end and attached to the positive end. Radiating bundles of actin filaments with diameters of $0.1-0.2 \mathrm{~mm}$ and a length of several micrometers lead to membrane protrusions called filopodia and finally initiate the cell's movement [13, 32].

Intracellular signalling enzyme phosphatidilinositol-3'-kinase (PI-3'-kinase) is of great significance in the leukocyte locomotion both under normal conditions and in case of different pathologies [2]. Leukocyte structural changes and preactivation in DM are caused by alteration in the expression level of PI-3'-kinase [35]. PI-3'-kinase takes part in signal transduction into the cell and from it, as well as in the formation of focal contacts on the leucocyte membrane surface by interaction with integrin receptors [37]. Among cellular proteins, which are the targets of PI-3'-kinase, there are low-molecularweight GTPases, which take part in the formation of such cell responses to the external stimulation as formation of stress fibrils, creation of lamellipodia and filopodia, i.e. they contribute to changes of the morphologic state of cells and movement [13]. All these occurs as a result of reorganization of the cellular actin cytoskeleton [28]. Consequently, the study of actin polymerization level in the peripheral blood leukocytes allows us to characterize leukocyte's pre-migration ability before extravasation (diapedesis).

Cooperative interaction between blood polymorphonuclear leukocytes (PMN) and mononuclears is an important factor in the maintanence of homeostasis under normal and pathological conditions. Inflammation in diabetes mellitus leads to decreased leukocyte-endothelial cell interactions and reduced number of leukocytes in inflamed lesions [3]. Previous studies have described diminished polymorphonuclear leukocytes functional activity (e.g., defective chemotaxis, bacterial killing, superoxide production, leukotriene release, and lysosomal-enzyme secretion) as well as altered basal levels of intracellular calcium and superoxide in diabetes. Thus, the nature and extent of PMN dysfunction under DM conditions remains to be elucidated [25, 34]

There are numerous methods for characterization of the functional state of immunocompetent blood cells. Most of them are not all-purpose as they are focused on the

ISSN 1996-4536 (print) • ISSN 2311-0783 (on-line) • Біологічні Студії / Studia Biologica • 2014 • Том 8/№3-4 • C. 17-30 
investigation of separate sections of pathogenesis. Therefore, there is a great need in expanding the means of investigation of the cell morphofunctional state alterations which often indicate certain pathologies.

The search for new substances that could be used in the combination therapy of DM is highly topical. Such substances are expected to improve the patient's condition due to their ability to decrease the level of glucose and normalize carbohydrate metabolism. Correction of actin polymerization defect in diabetes could improve the prognosis of diabetic vascular complications [1].

In the current work the biochemical effects of agmatine have been studied. Agmatine is a polyamine which is synthesized in the organism in negligible concentrations by decarboxylation of the amino acid L-arginine. Agmatine is considered to be of great therapeutic potential due to the various physiological and pharmacological effects it causes $[20,29]$. Agmatine acts as a neurotransmitter and neuromodulator; it is an endogenous ligand for imidazoline (I1/l2) receptors and $\alpha 2$-adrenoceptors, as well as N-methyl-Daspartate- and serotonine receptors [31]. Since agmatine is an analog of L-arginine it is also considered as an NO synthase concurrent inhibitor, especially of its inducible isoform [6]. One of the major biological effects of agmatine is its capacity to influence glucose metabolism at hyperglycemia. This effect of agmatine is achieved through a receptormediated mechanism [20]. Our previous studies have demonstrated that agmatine administration to animals with DM leads to normalization of glucose level [14]. It has also been shown that agmatine injections do not impact on the cytological peripheral blood parameters in animals with experimentally induced DM. The leukocyte count in diabetic animals returns to the indices close to that of the control group of animals. However, little information is available about the effects of agmatine on actin content and polymerization in leukocytes under experimental diabetes mellitus.

The purpose of our work was to study the effects of agmatine on actin polymerization in rats' peripheral blood leukocytes under normal and experimental DM conditions.

\section{MATERIALS AND METHODS}

In our study we used fluorescent microscopy assay and immunoblot analysis. The cells were stained with Phalloidin Alexa Fluor 350 with subsequent fluorescent microscopy in order to determine the level of actin polymerization. Both short and long F-actin filaments were visualized by this means. We performed the densitometric analysis of Western blots using anti-actin antibodies to measure the total level of actin (F-actin + G-actin) in white blood cells taken from different experimental groups of animals. Furthermore, we investigated the redistribution of actin within three cellular fractions: actin forming cytoskeletal filaments, the membrane skeleton filaments, and free G-actin monomers.

Animal preparation. The experiments were perfomed on white outbred male rats weighing 150-180 g. The animals had free access to food and water during their stay under standard vivarium conditions. The experiments were conducted in compliance with the General Ethical Principles for Conducting Experiments on Animals adopted at the First National Congress on Bioethics (Kyiv, 2001), which agree with the provisions of the European Convention for the Protection of Vertebrate Animals used for Experimental and Other Scientific Purposes (Strassbourg, 1985). The animals were divided into four experimental groups: (1) control, (2) control + agmatine, (3) experimental diabetes mellitus (EDM), and (4) EDM + agmatine. EDM was induced by the intraperitoneal administration of $6 \mathrm{mg}$ streptozotocin (Sigma, United States) per $100 \mathrm{~g}$ of body

ISSN 1996-4536 (print) • ISSN 2311-0783 (on-line) • Біологічні Студії / Studia Biologica • 2014 • Том 8/№3-4 • С. 17-30 
mass, dissolved in $10 \mathrm{mM}$ citrate buffer ( $\mathrm{pH}$ 5.5). The development of diabetes was controlled by the blood glucose level determined $72 \mathrm{~h}$ after the streptozotocin administration. Animals with a glucose level above $14 \mathrm{mM}$ were considered eligible for experiments. Starting on the third day from the moment of inducing diabetes, the animals from the second and fourth groups were intramuscularly administered with agmatine (Sigma, United States) at a concentration of $20 \mathrm{mg} / \mathrm{kg}$ body weight for 14 days.

Blood collection. Blood was collected after light anesthesia with diethylether. Heparin was added before hand to prevent coagulation (the end point heparin : whole blood dilution $=1: 100$ ).

Isolation of blood leukocytes. Leukocytes were isolated from blood by centrifugation in gradient of ficolltriombrast density $(r=1.076-1.078)$. Afterwards, the cells were washed twice in phosphate buffered saline (PBS, pH 7.4). Cell viability was controlled by trypanblue $(0.1 \% \mathrm{w} / \mathrm{v}$ solution) exclusion test.

Immunofluorescence studies. Fluorescent and biotinylated phalloidin and phallacidin are widely used in molecular biology assays for F-actin labeling. These phallotoxins, isolated from the deadly Amanitaphalloides mushroom, are bicyclic peptides that differ by two amino acid residues. They can be used interchangeably in most applications and bind competitively to the same sites in F-actin. Phalloidin and phallacidin contain an unusual thioether bridge between a cysteine and tryptophan residue that forms an inner ring structure. Labeled phallotoxins have similar affinity for both long and short filaments, binding in a stoichiometric ratio of about one phallotoxin molecule per actin subunit in muscle and nonmuscle cells from many different species of plants and animals. They reportedly do not bind to monomeric G-actin, unlike some anti-actin antibodies. Unlike antibodies, the binding affinity does not change appreciably with actin from different species or sources. Nonspecific staining is negligible, and the contrast between stained and unstained areas is extremely large [7].

Cells (1.0×106/coverslip) were washed with ice-cold PBS ${ }^{+}(200 \mathrm{mg} / \mathrm{KCl}, 200 \mathrm{mg} / \mathrm{l}$ $\mathrm{KH}_{2} \mathrm{PO}_{4}, 2.160 \mathrm{~g} / \mathrm{Na}_{2} \mathrm{HPO}_{4} \times 7 \mathrm{H}_{2} \mathrm{O},-8.0 \mathrm{~g} / \mathrm{l} \mathrm{NaCl}, 100 \mathrm{mg} / \mathrm{CaCl}_{2}, 100 \mathrm{mg} / \mathrm{l} \mathrm{MgCl} \times$ $\left.6 \mathrm{H}_{2} \mathrm{O}, \mathrm{pH} 7.5\right)$ and transferred onto ice. Cells were fixed with $4 \%$ methanol-free paraformaldehyde in $\mathrm{PBS}^{+}\left(10 \mathrm{~min}, 4^{\circ} \mathrm{C}\right.$ and $20 \mathrm{~min}, 25^{\circ} \mathrm{C}$ ), exposed to $50 \mathrm{mM} \mathrm{NH}_{4} \mathrm{Cl} / \mathrm{PBS}^{+}$ $\left(5 \mathrm{~min}, 25^{\circ} \mathrm{C}\right)$ and $3 \% \mathrm{BSA}$ in TBS $\left(30 \mathrm{~min}, 25^{\circ} \mathrm{C}\right)$. Cells were permeabilized with $0.03 \%$ Triton X-100/PBS ${ }^{+}\left(10 \mathrm{~min}, 25^{\circ} \mathrm{C}\right)$, blocked with $3 \% \mathrm{BSA} \mathrm{PBS}^{+}\left(30 \mathrm{~min}, 25^{\circ} \mathrm{C}\right)$ and incubated with phalloidin-Alexa Fluor 350 (Invitrogen, CA). Incubation was conducted for $60 \mathrm{~min}$ at $25^{\circ} \mathrm{C}$ in TBS/0.2\% BSA. Samples were mounted in mowiol/DAB$\mathrm{CO}$ and examined under a fluorescent microscope (Nikon Optiphot 2). The number of cells was counted and the cell length was measured on the yielded images using ImageJ software. The calculations were performed in four-five independent experiments from 10 to 15 fields containing a total of 100 to 150 cells for each sample.

Fractionation of actin cytoskeleton. Cells $\left(1.5 \times 10^{6}\right)$ were lysed in $250 \mathrm{ml}$ of the buffer composed of $0.5 \%$ Triton X-100, $100 \mathrm{mM} \mathrm{KCl,} 5 \mathrm{mM} \mathrm{MgCl}, 2 \mathrm{mM}$ EGTA, $25 \mathrm{mM}$ Tris, pH 7.5 and a protease inhibitor cocktail ("Sigma", USA). After $10 \mathrm{~min}\left(4^{\circ} \mathrm{C}\right)$, cell lysates were centrifuged for $10 \mathrm{~min}$ at $10000 \mathrm{~g}$. The yielded pallet contained long cytoskeletal actin filaments, while the supernatant contained short actin filaments and actin monomers $[15,19]$. After withdrawing $10 \mathrm{ml}$-samples of supernatant for SDS-PAGE analysis, the supernatants were subjected to further high-speed centrifugation $(1 \mathrm{~h}, 100000 \mathrm{~g})$ to separate actin monomers (supernatant) and short actin filaments (pellet). The pellet was dissolved in $30 \mathrm{ml}$ of urea solution and analyzed by SDS-PAGE. To quantify actin in isolated fractions, equal volume of each fraction was applied onto a gel [21]. After immune

ISSN 1996-4536 (print) • ISSN 2311-0783 (on-line) • Біологічні Студії / Studia Biologica • 2014 • Том 8/№3-4 • C. 17-30 
blot with anti-actin antibody, actin bands were analyzed densitometrically using Gelpro32. Actin content in each fraction was expressed as a percentage of actin amount found in leukocytes of control group in the corresponding set of fractions.

Immune blot analysis. The lysates as well as cellular fractions were subjected to SDS-PAGE, transferred onto the nitrocellulose sheets and immune blot analysis was performed essentially as described $[23,24]$. The membranes were probed with mouse IgG anti-actin antibody (MP Biomedicals, OH) followed by anti-mouse IgG-peroxidase (Sheep anti-Mouse Ig Antibody, (H+L) HRP conjugate, Millipore, CШA). The immunoreactive bands visualized by chemiluminescence (Pierce, IL) were analyzed densitometrically using Gelpro32.

Data analysis. The significance of differences between the groups was calculated using Student's t-test. $\mathrm{P}<0.05$ was considered to be statistically significant.

\section{RESULTS AND DISCUSSION}

We determined the amount of polymerized actin in cells by assessing the content of fluorescent phalloidin, which binds exclusively to F-actin in a 1:1 ratio leaving G-actin unlabeled [9]. We studied F-actin levels in leukocytes from control animals and animals with experimental DM. Furthermore, we described the impact of agmatine (which was administered intramuscularly during 14 days) on actin polymerization in leukocytes from healthy animals and animals with experimental DM.

Localization and level of F-actin in leukocytes from all experimental groups of animals were evaluated using Phalloidin-Alexa Fluor 350 staining and subsequent fluorescent microscopy (Fig. 1). We analyzed signal intensities from separate cells; arithmetic means of signal intensities from different cells are represented in the Table 1. The comparative analysis of fluorescent and light microscopy revealed that polymorphonuclear leukocytes possess higher level of F-actin when compared to mononuclear leukocytes. F-actin cytoskeleton filaments of PMN cells are involved in intercellular interactions as they are capable of forming adhesive contacts. Cytoskeletal actin filaments also play role in signal transduction and leukocyte motility [30]. The filaments determine the cell shape; majority of the actin filaments are concentrated in the periphery of cell next to the plasma membrane. F-actin is localized in filopodia, lamellipodia, ruffles, and the actinrich cell cortex [18]. There are two types of F-actin that differ in stability. The lamellipodia F-actin is sensitive to chemotactic factor stimulation [18]. This form of actin determines the neutrophil's facility for activation, adhesion, motility, phagocytosis and cytotoxicity [30]. Actin cytoskeleton permanently undergoes dynamic reorganization in order to secure all of the cell's morphofunctional changes and leukocyte functions. [8]. In contrast, F-actin of the cortex is characterized by low stability. It is present in both stimulated and unstimulated neutrophils [18].

In our studies we demonstrated that the baseline (spontaneous) level of the polymerized actin in leukocytes of diabetic rats was higher when compared with that in leukocytes of the control group. This implies that under experimental diabetes mellitus leukocytes undergo certain morphofunctional changes and are in pre-activated state. Preactivated neutrophils at EDM develop ruffles all over the cell body [18]. The fivefold increase in polymerized actin level in leukocytes of diabetic rats implies that the polymerized actin accumulates in the filopodia region of leukocytes [18]. The literature data [1] indicate that even threefold rise in polymerized actin level is associated with an insufficient cellular response to integrin-dependent cell-cell signaling, which leads to diminished cell-matrix interactions [17]. We suggest that the rise of actin level at EDM conditions leads to the

ISSN 1996-4536 (print) • ISSN 2311-0783 (on-line) • Біологічні Студії / Studia Biologica • 2014 • Том 8/№3-4 • С. 17-30 
decrease of leukocyte's adhesion to endothelial cells. This affects the cell's ability for diapedesis and prevents them from migration to the inflamed lesion. All these changes lead to a decreased number of leukocytes at the site of infection [3].

Table 1. The level of the polymerized actin in leukocytes of rats under normal conditions and in the case of experimental diabetes mellitus ( $M \pm m, n=4-5)$

Таблиця 1. Вміст полімеризованого актину в лейкоцитах щурів у нормі та за умов експериментального цукрового діабету ( $\mathrm{M} \pm \mathrm{m}, \mathrm{n}=4-5)$

\begin{tabular}{l|c}
\multicolumn{1}{c|}{ Groups } & $\begin{array}{c}\text { Levels of F-actin } \\
\text { (Conventional Units) }\end{array}$ \\
\hline Control & $1.19 \pm 0.18$ \\
\hline Experimental diabetes mellitus (EDM) & $6.22 \pm 1.12^{*}$ \\
\hline Control + agmatine & $16.51 \pm 2.09^{*}$ \\
\hline EDM + agmatine & $8.86 \pm 0.90^{\#}$ \\
\hline
\end{tabular}

Comments: * $-\mathrm{P}<0.05$, as compared with the control group; \# $-\mathrm{P}<0.05$, as compared with the diabetes mellitus group.

Примітки: * - різниця достовірна порівняно з контролем, $\mathrm{P}<0,05$; - різниця достовірна порівняно з ЕЦД, $\mathrm{P}<0,05$.

In the present work, we have studied the effect of agmatine on the level and localization of F-actin in leukocytes from normal and diabetic rats (Table 1, Fig. 1). In leukocytes from control animals and animals with experimental DM an increased level of polymerized actin was observed in response to agmatine treatment. In response to agmatine treatment the cells of control rats were mostly rounded with actin filaments forming a cortical ring (Fig. 1). Notably, agmatine injection caused the fourteenfold increase of the actin level of peripheral blood leukocytes of healthy animals (Table 1). Agmatine treatment of animals with experimentally induced diabetes mellitus resulted in an increased actin level when compared to untreated diabetic rats (Table 1).

The initial general F-actin level in leukocytes of diabetic rats treated with agmatine was substantially higher than in leukocytes of untreated diabetic rats (Table 1, Fig. 1). Factin level in leukocytes of agmatine-treated and untreated diabetic rats was $8.86 \pm 0.90$ and $6.22 \pm 1.12$ conventional units respectively. Elevated actin levels in the leukocytes from agmatine-treated diabetic rats can be explained by quantitative redistribution of immunocompetent white cells. Previous studies demonstrated that agmatine injections normalized the numbers of neutrophils and lymphocytes while the number of monocytes increased [14].

The leukocyte count of animals with diabetes mellitus is characterized by the diminished level of segmented neutrophils and increased level of lymphocytes, while the numbers of banded neutrophils, eosinophils and monocytes remain constant. Such changes in the leukocyte's ratio indicate that the specific immune response prevails over innate response at the EDM conditions [14]. Efficacious immune system functioning requires not only normal leukocyte count but also unaffected capacity of cells to migrate to the site of inflammation [26]. Neutrophil granulocytes are the first cells that get activated in response to pro-inflammatory factors [38]. Agmatine administration to animals with EDM leads to normalization of leukocytes and neutrophils numbers. An increase in F-actin level reflects the improvement in both specific and innate immune responses [14].

ISSN 1996-4536 (print) • ISSN 2311-0783 (on-line) • Біологічні Студії / Studia Biologica • 2014 • Том 8/№3-4 • С. 17-30 


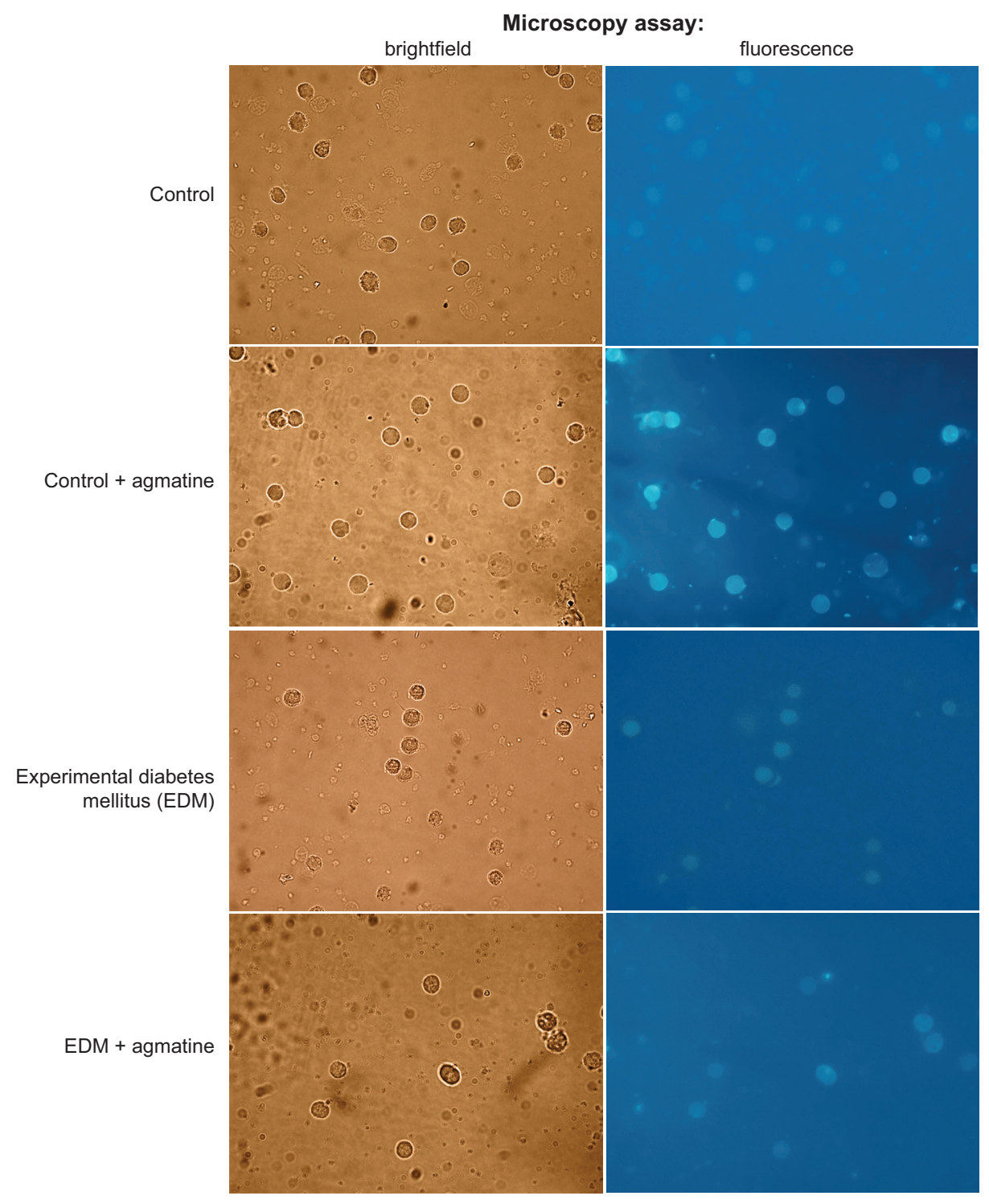

Fig. 1. Representative brightfield and fluorescent images of leukocytes from different groups of rats. Leukocytes were stained with phalloidin-Alexa Fluor 350 in order to obtained visualize actin filaments after fixation and permeabilization. Magnification $\times 1000$

Рис. 1. Репрезентативні мікрофотографії світлової та фрлюоресцентної мікроскопії лейкоцитів після фіксування, пермеабілізування й інкубування клітин з Phalloidin Alexa Fluor 350 для візуалізації актинових фріламентів у всіх досліджуваних групах тварин. Збільшення ×1000

It is possible that the changes in the leukocyte count in diabetic rats after agmatine treatment were caused by agmatine's ability to alter polyamine metabolism. Agmatine, after being actively transported into the cell via putrescine transporter, causes the exhaustion of the intracellular polyamine level. As the activity of polyamine transporters correlates with the cell's proliferative activity agmatine mainly affects the cells with high proliferative 
activity $[5,33]$. Taking into account the increase in lymphocyte number and that the number of banded neutrophils remains constant in diabetic rats we suggest that agmatine normalizing action can be explained by inhibition of white blood cell precursors' proliferation in bone marrow. A notable increase in the level of polymerized actin in both healthy and diabetic rats' leukocytes due to agmatine injections indicates that agmatine directly or indirectly affects the functional state of cells in the bloodstream or bone marrow.

To study the process or $\mathrm{F}$ actin cytoskeleton reorganization we performed some further studies. Cells were lysed with Triton X-100 and then centrifuged at low speed $(10000 \mathrm{~g})$ (Fig. 2, A). Separate fractions of cytoskeletal and cytosol proteins were yielded. Long cytoskeletal actin filaments concentrated in the pellet while supernatant contained short F-actin filaments and G-actin monomers. The immunoblot analysis revealed the total actin content in all groups of animals (Fig. 2, B, C and Fig. 3). General actin content (the sum of the two fractions described above) in the leukocytes from healthy animals was considered as $100 \%$; general actin content from the leukocytes from other groups of animals was compared to that in the control group (Fig. 3).

General actin content in leukocytes from diabetic rats was $24 \%$ lower than that in the leukocytes from healthy rats. Agmatine administration to animals with experimental DM caused the $46 \%$ increase in general actin content when compared to diabetic rats. Peripheral blood leukocytes from healthy animals that received agmatine injections were characterized by $22 \%$ decrease in actin level if compared to control animals (Fig. 3).

Literature data suggest that the increase in general actin content in leukocytes can be explained by an increase in polymerized actin level in neutrophil granulocytes [22, 39]. Thus we believe that the increase in general polymerized actin level in diabetic rats' leukocytes is due to the increased neutrophil number [14] and the elevated actin level in neutrophils compared to lymphocytes [22, 30, 39]. Furthermore, beneficial agmatine properties include its capacity to prevent hyperglycemia-induced metabolic disorders $[26,18]$ as agmatine is known to decrease the glucose level in the bloodstream of diabetic rats [14, 20].

Analyzing actin reorganization between long cytoskeleton filaments and short actin filaments (Fig. 2, B) we established that in leukocytes from diabetic animals the level of long actin filaments decreases while the level of short actin filaments increases (Fig. 4, $A$ ). Agmatine administration to healthy rats did not lead to redistribution among these two forms of actin. In contrast, agmatine injections to diabetic rats resulted in elevated level of long actin filaments while the level of short filaments was diminished. We suggest that this increase in long actin filaments level is due to the reorganization and depolymerization of short actin filaments (Fig. 4, $A$ ).

As displayed on the Fig. 2, $A$, further high-speed centrifugation $(100000 \mathrm{~g})$ of the supernatant, yielded from the previous low-speed centrifugation resulted in short actin filaments and actin monomers segregation.

We performed a comparative analysis of actin reorganization between cytoskeletal filaments, short actin filaments and actin monomers (Fig. 2, C and 4, B). In leukocytes of the control group these three forms of actin represented respectively $71.9 \pm 7.2$, $8.7 \pm 1,1$, and $19.4 \pm 1.3 \%$ from the general actin content. Polymerized vs monomeric actin were in ratio 8:2. In leukocytes from diabetic rats cytoskeletal actin filaments, short actin filaments and actin monomers were distributed as $44.3 \pm 4.2,44.3 \pm 4.4$, and $11.4 \pm 1.2 \%$ respectively. Polymerized actin was 9 -fold more abundant than monomeric actin in this experimental group. These data show that although general actin content in leukocytes at DM diminishes (Fig. 3) the process of actin polymerization intensifies (Fig. $4, B$ ). It should be noted that leukocytes at DM are characterized by higher level of short actin filaments when compared to control animals.

ISSN 1996-4536 (print) • ISSN 2311-0783 (on-line) • Біологічні Студії / Studia Biologica • 2014 • Том 8/№3-4 • C. 17-30 
$A$

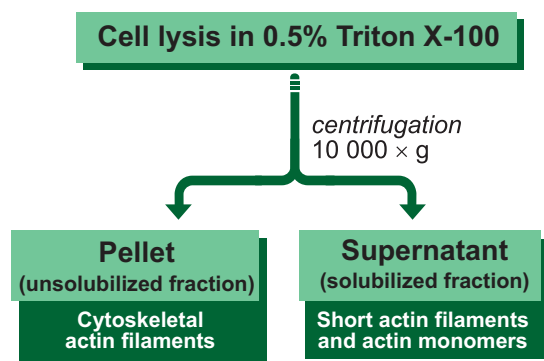

$B$

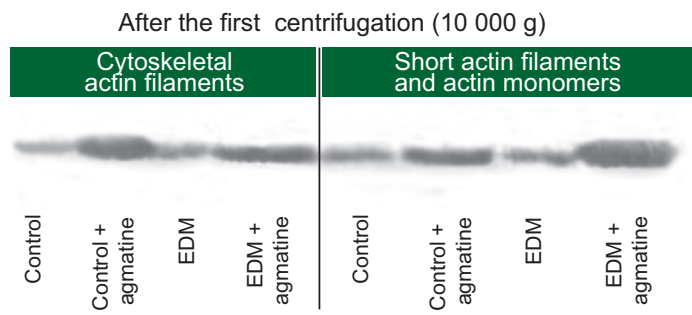

C

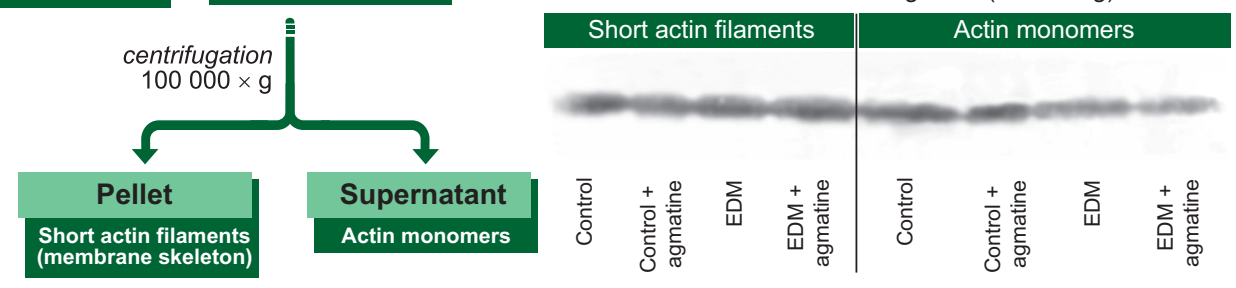

Fig. 2. The immune blot analysis of actin content in leukocytes of healthy rats, rats with experimental diabetes mellitus and after agmatine treatment: $\boldsymbol{A}$ - scheme of fractionation of $0.5 \%$ Triton X-100 cell lysates into fractions containing cytoskeletal actin filaments, short actin filaments of the membrane skeleton, and actin monomers; $\boldsymbol{B}$ - fractions which contained cytoskeletal actin filaments and both short actin filaments and actin monomers from leukocytes from all groups of animals were analyzed by immune blot analysis to determine actin contents in each fraction. Equal volume of each fraction was applied onto the gel. Proteins from $1.5 \times 10^{6}$ cells were loaded per lane; $\boldsymbol{C}$ - fractions which contained short actin filaments and actin monomers were analyzed by immune blot analysis to determine actin contents in each fraction. Equal volume of each fraction was applied onto the gel. Proteins from $1.5 \times 10^{6}$ cells were loaded per lane

Рис. 2. Дослідження рівня актину методом імуно-блот-аналізу в лейкоцитах щурів за нормальних умов, за умов експериментального цукрового діабету та після введення агматину: $\boldsymbol{A}$ - схема фракціонування лізатів, одержаних шляхом лізису клітин за допомогою 0,5 \% Triton X-100, для відокремлення фракцій, що містять цитоскелетні актинові фріламенти, короткі актинові фріламенти й мономери актину; $\boldsymbol{B}$ - для виявлення рівня актину був проведений імуно-блот-аналіз фракцій, що містили довгі цитоскелетні актинові фріламенти, і фракцій з короткими актиновими фріламентами й актиновими мономерами. Рівні аліквоти кожної фракції вносили в гель. В одну лунку гелю вносили білки $31,5 \times 10^{6}$ клітин; $\boldsymbol{C}$ - для виявлення вмісту актину був проведений імуноблот-аналіз фракцій, що містили короткі актинові фріламенти й актинові мономери. Рівний об'єм кожної фракції вносили в гель. В одну лунку гелю вносили білки з 1,5×106 клітин

Actin polymerization can occur via two distinct pathways: first is actin nucleation through activation of the Arp2/3 complex resulting in de novo polymerization of actin filaments. Second is the elongation of pre-existing actin filaments ("enhanced actin polymerization") requiring uncapping and severing of actin filaments [32]. We suggest that the second path is dominating at the conditions of agmatine treatment. Short actin filaments initiate polymerization in response to leukocyte activation. This results in filopodia formation on the membrane surface [18].

After agmatine administration, the actin content in each fraction of leukocytes of control rats represented, respectively, $72.3 \pm 6.9,17.9 \pm 1.5$, and $9.8 \pm 0.8 \%$ (Fig. $4, B$ ). In agmatine-treated diabetic group, these three actin forms represented, respectively,

ISSN 1996-4536 (print) • ISSN 2311-0783 (on-line) • Біологічні Студії / Studia Biologica • 2014 • Том 8/№3-4 • С. 17-30 
$69.3 \pm 6.6,17.1 \pm 1.6$, and $13.6 \pm 1.1 \%$. In these two groups polymerized actin and monomeric actin were in 9:1 ratio. Our data implies that agmatine administration to diabetic animals with increased actin contents in their leukocytes (Fig. 3) leads to further actin polymerization in the cytoskeleton fraction while short actin filaments undergo depolymerization (Fig. 4, B). The content of the short actin filaments decreases 2,5-fold in such animals when compared to diabetic animals who did not receive agmatine injections (Fig. 4, B). Agmatine administration to healthy rats did not lead to significant changes in the general actin content (Fig. 3), while the level of actin monomers decreased as the result of intense polymerization (Fig. 4, B).

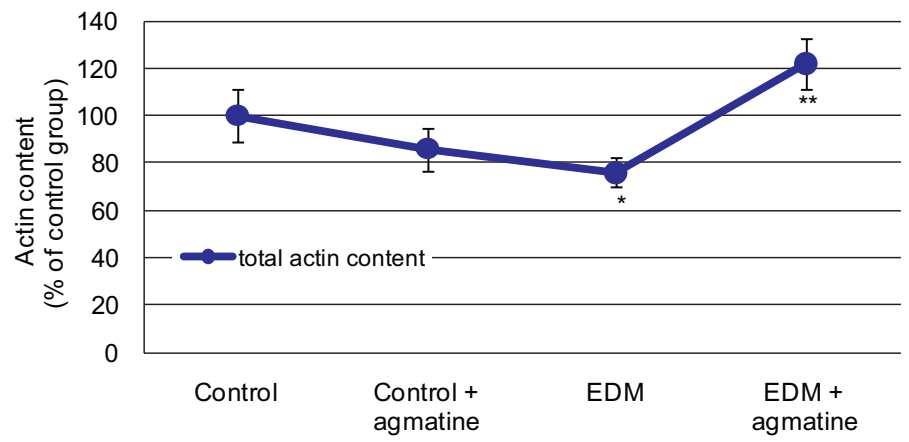

Fig. 3. Quantification of total actin (total content of cytoskeletal actin filaments, short actin filaments and actin monomers) in rat leukocytes. The analysis was based on densitometry of immune blots

Рис. 3. Кількісне визначення загального вмісту актину (суми довгих цитоскелетних актинових філаментів, коротких філаментів і мономерів актину) в лейкоцитах щурів. Дані одержані за допомогою денситометрії імуноблотів

We suggest that the reorganization of actin cytoskeleton in leukocytes of diabetic rats is a result of leukocytes' transition into a pre-activated state. This transition may occur because of the translocation of the PI-3'-kinase activated regulatory subunit to the cytoskeleton sites which are responsible for the integrin-dependent cell focal adhesion $[2,35]$. PI-3'-kinase and its products play a pivotal role in the cytoskeleton reorganization [32]. PI-3'-kinase products (phosphatidylinositol-3,4-bisphosphate and phosphatidylinositol-1,3,4,-trisphosphate) cause the dissociation of cap proteins from actin filaments, which activates actin polymerization. Phosphatidylinositols can also prevent the phosphorylation of actin-regulatory proteins. Such proteins decrease the content of cytoskeletal actin filaments and increase the level of actin monomers [21].

Under diabetes mellitus conditions, short actin filaments alter the morphology and functions of pre-activated leukocytes. In diabetic animas the content of these short filaments was $44.3 \%$, while agmatine administration caused a substantial decrease (to $17.1 \%$ ) in the short filaments level (Fig. 4, B). These data suggest that actin cytoskeleton polymerization after agmatine administration occurs due to further polymerization of the short filaments (Fig. 4, B). It has also been shown that agmatine injections lead to leukocytes' transition from the pre-activated state to the state of dynamic sphere, which is ensured by cytoskeletal actin filaments $[4,13]$.

Thus we have demonstrated by two different methods (fluorescent microscopy and immune blot analysis) that agmatine affects the leukocyte functional state under DM conditions via reorganization of actin cytoskeleton filaments. 


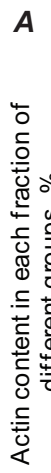

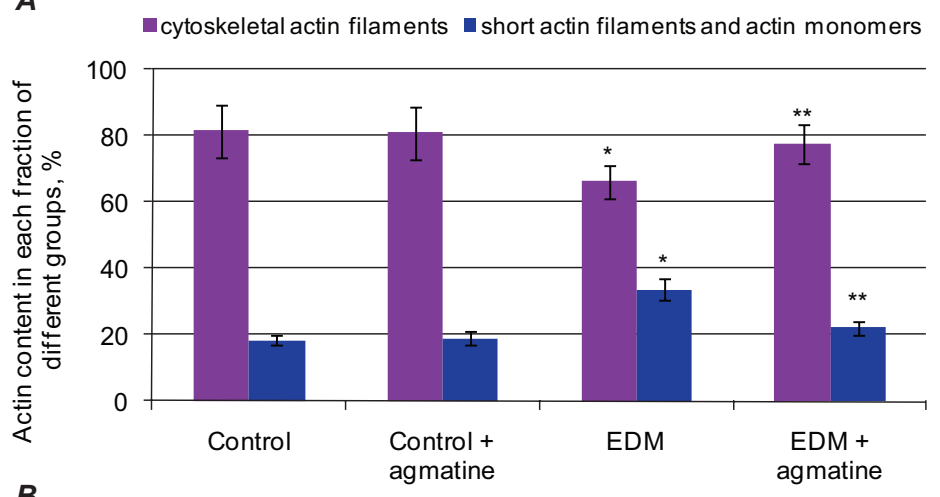

B

wcytoskeletal actin filaments $\square$ short actin filaments

actin monomers

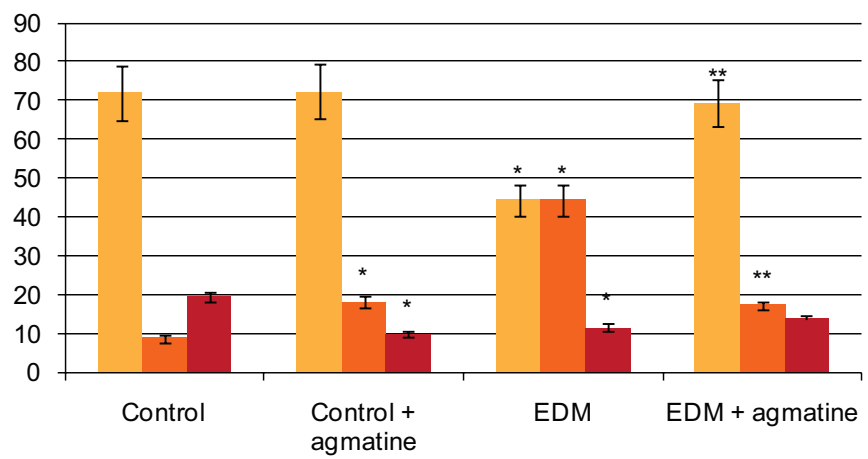

Fig. 4. Actin content in different fractions of leukocyte lysates: $\boldsymbol{A}$ - quantification of actin in fractions containing cytoskeletal filaments, or a mixture of actin monomers and short actin filaments. Analysis based on densitometry of immune blots as in (Fig. 2, B). Actin content in each fraction of different groups was expressed as a percentage of total actin amount (Fig. 3) found for each studied group; $\boldsymbol{B}$ - quantification of actin in fractions containing cytoskeletal filaments. short actin filaments or actin monomers. The analysis was based on densitometry of immunoblots as in (Fig. 2, B, C). Actin content in each fraction of different groups was expressed as a percentage of total actin amount (Fig. 3) found for each studied group.

Data are expressed as a mean \pm SEM from three experiments: * Significantly different from cells of control rats at $\mathrm{P}<0.05 ;{ }^{* *}$ Significantly different from cells of EDM group at $\mathrm{P}<0.05$

Рис. 4. Вміст актину в різних фракціях лізатів лейкоцитів: $\boldsymbol{A}$ - Кількісне визначення вмісту актину у фрракціях лізатів лейкоцитів, що містили тільки довгі цитоскелетні актинові філаменти, а також тих, що містили суміш коротких актинових фріламентів і актинові мономери. Дані одержані за допомогою денситометрії імуноблотів (рис. 2, В). Вміст актину в кожній фракції виражений як відсоток від загального вмісту актину (рис. 3), визначений для відповідної групи; $\boldsymbol{B}$ - кількісне визначення вмісту актину у фракціях лізатів лейкоцитів, що містили довгі цитоскелетні актинові фріламенти, короткі актинові філаменти або актинові мономери. Дані одержані за допомогою денситометрії імуноблотів (рис. 2, B, C). Вміст актину в кожній фрракції виражений як відсоток від загального вмісту актину (рис. 3), визначений для відповідної групи.

Дані представлені як середнє арифметичне \pm стандартна похибка середнього арифметичного з трьох експериментів: * достовірність відхилення від значень клітин контрольних щурів $\mathrm{P}<0,05 ;{ }^{* *}$ достовірність відхилення від значень клітин щурів з цукровим діабетом - $\mathrm{P}<0,005$

1. Advani A., Marshall S., Thomas T. Increasing neutrophil F-actin corrects CD11b exposure in Type 2 diabetes. Eur. J. Clin. Invest, 2004; 34(5): 358-364.

2. Aiba Y., Kameyama M., Yamazaki T. et al. Regulation of B-cell development by BCAP and CD19 through their binding to phosphoinositide 3-kinase. Blood, 2008; 111(3): 1497-1503.

ISSN 1996-4536 (print) • ISSN 2311-0783 (on-line) • Біологічні Студії / Studia Biologica • 2014 • Том 8/№3-4 • С. 17-30 
3. Alba-Loureiro T.C., Munhoz C.D., Martins J.O. et al. Neutrophil function and metabolism in individuals with diabetes mellitus. Brazilian Journal of Medical and Biological Research, 2007; 40: 1037-1044.

4. Algeciras-Schimnich A., Shen L., Barnhart B.C. et al. Molecular ordering of the initial signaling events of CD95. Mol. Cell Biol, 2002; 22: 207-220.

5. Arndt M.A, Battaglia, V., Parisi E. et al. The arginine metabolite agmatine protects mitochondrial function and confers resistance to cellular apoptosis. Am. J. Physiol. Cell. Physiol, 2009; 296: 1411-1419.

6. Auguet M., Viossat I., Marin J.G., Chabrier P.E. Selective inhibition of inducible nitric oxide synthase by agmatine. Jpn. J. Pharmacol, 1995; 69(3); 285-287.

7. Biochemistry. Molecular probes. Section 11.1 Probes for Actin. 33, 14387, 1994: 455-462 I www.probes.com.

8. Cano M.L., Cassimeris L., Fechheimer M., Zigmond S.H. Mechanisms Responsible for F-actin Stabilization after Lysis of Polymorphonuclear Leukocytes. The J. of Cell Biology, 1992; 116(5): 1123-1134.

9. Carulli G., Mattii L., Azzara A. et al. Actin Polymerization in Neutrophils from Donors of Peripheral Blood Stem Cells: Divergent Effects of Glycosylated and Nonglycosylated Recombinant Human Granulocyte Colony-Stimulating Factor. American Journal of Hematology, 2006; 81: 318-323.

10. Cicchetti G., Allen P.G., Glogauer M. Chemotactic signaling pathways in neutrophils: from receptor to actin assembly. Crit. Rev. Oral. Biol. Med, 2003; 13: 220-228.

11. Clevers H., Dunlap S., Terhorst C. The transmembrane orientation of the e chain of the TcR/ CD3 complex. European J. of Immunology, 2005; 18(5): 705-710.

12. Collison K.S., Parhar R.S., Saleh S.S. et al. RAGE-mediated neutrophil dysfunction is evoked by advanced glycation end products (AGEs). J. Leukocyte Biology, 2002; 71: 433-444.

13. Fais $S$., Malorni $W$. Leukocyte uropod formation and membrane/cytoskeleton linkage in immune interactions. J. of Leukocyte Biology, 2003; 73: 556-563.

14. Ferents I.V., Brodyak I.V., Lyuta M. Ya. et al. Effect of agmatine on the blood system parameters of rats under the condition of experimental diabetes mellitus. Studia Biologica, 2012; 6(3): 65-72.

15. Fox J.E., Boyles J.K., Berndt M.C. et al. Identification of a membrane skeleton in platelets. J. Cell Biol, 1988; 106: 1525-1538.

16. Giammarioli A.M., Garofalo T., Sorice M. et al. GD3 glycosphingolipid contributes to Fas-mediated apoptosis via association with ezrin cytoskeletal protein. FEBS Lett, 2001; 506: 45-50.

17. Guo P., Zhang Y., Zhao J.H. et al. Regulation on the expression and N-glycosylation of integrins by N-acetylglucosaminyltransferase V. Biochem. Biophys. Res. Commun, 2003; 310(2): 619-626.

18. Hannigan M., Zhan L., Ai Y., Huang C.-K. Leukocyte-specific gene 1 protein (LSP1) is involved in chemokine $\mathrm{KC}$-activated cytoskeletal reorganization in murine neutrophils in vitro. J. of Leukocyte Biology, 2001; 69: 497-504.

19. Hartwig J.H., Shevlin P. The architecture of actin filaments and the ultrastructural location of actin-binding protein in the periphery of lung macrophages. J. Cell Biol, 1986; 103: 1007-1020.

20. Hwang S.L., Liu I.M., Tzeng T.F., Cheng J.T. Activation of imidazoline receptors in adrenal gland to lower plasma glucose in streptozotocin-induced diabetic rats. Diabetologia, 2005; 48(4): 767-775.

21. Kleveta G., Borzecka K., Zdioruk M. et al. LPS induces phosphorylation of actin-regulatory proteins leading to actin reassembly and macrophage motility. J. of Cellular Biochemistry, 2012; 113: 80-92.

22. Kong L., Ge B.X. MyD88-independent activation of a novel actin-Cdc42/Rac pathway is required for Toll-like receptor-stimulated phagocytosis. Cell Res, 2008; 18: 745-755.

23. Kwiatkowska K., Frey J., Sobota A. Phosphorylation of FcgRIIA is required for the receptorinduced actin rearrangement and capping: The role of membrane rafts. J. Cell Sci, 2003; 116: 537-550.

24. Kwiatkowska K., Sobota A. Engagement of spectrin and actin capping of FcgRII revealed by studies on permeabilized U937 cells. Biochem. and Biophys. Research Communications, 1999; 259(2): 287-293.

ISSN 1996-4536 (print) • ISSN 2311-0783 (on-line) • Біологічні Студії / Studia Biologica • 2014 • Том 8/№3-4 • C. 17-30 
25. McManus L.M., Bloodworth R.C., Prihoda T.J. et al. Agonist-dependent failure of neutrophil function in diabetes correlates with extent of hyperglycemia. J. Leukocyte Biology, 2001; 70: 395-404.

26. Mitoma $\mathrm{J}$. et al. Critical functions of $\mathrm{N}$-glycans in L-selectin-mediated lymphocyte homing and recruitment. Nat. Immunol, 2007; 8: 409-418

27. Niggli V. Signaling to migration in neutrophils: importance of localized pathways. Int. J. Biochem. Cell Biol, 2003; 35: 1619-1638.

28. Nunoi H., Yamazaki T., Kanegasaki S. Neutrophil cytoskeletal disease. Int. J. Hematol, 2001; 74(2): 119-124.

29. Özyazgan S., Bicakci B., Ozaydin A. et al. The effect of agmatine on the vascular reactivity in streptozotocin-diabetic rats. Pharmacol Res, 2003; 48(2): 133-138.

30. Pollard T.D., Borisy G.G. Cellular motility driven by assembly and disassembly of actin filaments. Cell, 2003; 112: 453-465.

31. Raasch W., Schafer U., Chun J., Dominiak P. Biological significance of agmatine, an endogenous ligand at imidazoline binding sites. Br. J. Pharmacol, 2001; 133(6): 755-780.

32. Samstag Y., Eibert S.M., Klemke M., Wabnitz G.H. Actin cytoskeletal dynamics in T lymphocyte activation and migration. J. of Leukocyte Biology, 2003; 73: 30-48.

33. Satriano J., Matsufujii S., Murakamii Y. et al. Agmatine suppresses proliferation by frameshift induction of antizyme and attenuation of cellular polyamine levels. J. Biol. Chem, 1998; 273(25): 15313-15316.

34. Sybirna N.O., Zdioryk M.I., Brodyak I.V. et al. Activation of the phosphatidylinositol-3'-kinase pathway of lectin-induced signal by siaolocontaining leukocytes membrane glycoprotein in healthy donors and under type 1 diabetes mellitus. Ukr. Biochem. J, 2011; 83(5): 22-31.

35. Sybirna N.O., Zdioryk M.I., Brodyak I.V. et al. Activation of the phosphatidylinositol-3'-kinase pathway of lectin-induced signal by siaolocontaining leukocytes membrane glycoprotein in healthy donors and under type 1 diabetes mellitus. Ukr. Biochem. J, 2011; 83(5): 22-31.

36. Tipu H.N., Ahmed T.A., Bashir M.M. Human Leukocyte Antigen Class II Susceptibility Conferring Alleles Among Non-Insulin Dependent Diabetes Mellitus Patients. J. of the College of Physicians and Surgeons Pakistan, 2011; 21(1): 26-29.

37. Yu W., Cassara J., Weller P.F. Phosphatidylinositide 3-kinase localizes to cytoplasmic lipid bodies in human polymorphonuclear leukocytes and other myeloid-derived cells. Blood, 2000, 95(3): 1078-1085.

38. Zemans R.I., Arndt P.G. Tec kinases regulate actin assembly and cytokine expression in LPSstimulated human neutrophiks via JNK activation. Cell Immunol, 2009; 258: 90-97.

39. Zemans R.I., Arndt P.G. Tec kinases regulate actin assembly and cytokine expression in LPSstimulated human neutrophiks via JNK activation. Cell Immunol, 2009; 258: 90-97.

\title{
ВПЛИВ АГМАТИНУ НА ПРОЦЕС ПОЛІМЕРИЗАЦІЇ АКТИНУ В ЛЕЙКОЦИТАХ ЩУРІВ ЗА УМОВ СТРЕПТОЗОТОЦИН-ІНДУКОВАНОГО ЦУКРОВОГО ДІАБЕТУ
}

\author{
I. В. Бродяк, І. І. Біла, М. Оверчук, Н. О. Сибірна \\ Львівський національний університет імені Івана Франка \\ вул. Грушевського, 4, Львів 79005, Україна \\ e-mail: sybirna_natalia@yahoo.com
}

3'ясовано, що агматин впливає на процес полімеризації актину в лейкоцитах периферичної крові щурів у нормі та за умов експериментального цукрового діабету (ЕЦД). Встановлено, що вихідний рівень полімеризованого актину в лейкоцитах за ЕЦД є достовірно вищим порівняно з контрольною групою тварин, що вказує на зміну структурно-функціональних властивостей і преактивований стан цих клітин у разі діабету. У лейкоцитах тварин з ЕЦД відбувається перерозподіл фракцій актину, а саме - на тлі зниження загального рівня актину зменшується

ISSN 1996-4536 (print) • ISSN 2311-0783 (on-line) • Біологічні Студії / Studia Biologica • 2014 • Том 8/№3-4 • С. 17-30 
кількість актинових фріламентів цитоскелету, але зростає вміст коротких актинових фріламентів. Отримані результати свідчать про те, що хоч вихідний вміст загального актину в лейкоцитах у разі ЕЦД знижується, сам процес полімеризації актину інтенсифрікується. Введення агматину контрольній групі тварин не викликало достовірних змін загального вмісту актину в лейкоцитах, проте призводило до зменшення кількості мономерів актину в результаті інтенсифрікації полімеризації під час утворення фрракції коротких фріламентів. Тоді як у тварин з ЕЦД цей поліамін сприяв підвищенню як загального вмісту актину, так і рівня полімеризованого актину у фракції фріламентів цитоскелету внаслідок реорганізації (деполімеризації) коротких актинових фріламентів. Отже, агматин або прямо, або опосередковано впливає на функціональний стан лейкоцитів через процеси формування елементів цитоскелету.

Ключові слова: актин, цитоскелет, лейкоцити, агматин, експериментальний цукровий діабет.

\title{
ВЛИЯНИЕ АГМАТИНА НА ПРОЦЕСС ПОЛИМЕРИЗАЦИИ АКТИНА В ЛЕЙКОЦИТАХ КРЫС ПРИ СТРЕПТОЗОТОЦИН-ИНДУЦИРОВАННОМ САХАРНОМ ДИАБЕТЕ
}

\author{
И. В. Бродяк, И. И. Била, М. Оверчук, Н. А. Сибирная \\ Львовский национальный университет имени Ивана Франко \\ ул. Грушевского, 4, Львов 79005, Украина \\ e-mail: sybirna_natalia@yahoo.com
}

Показано, что агматин влияет на процесс полимеризации актина в лейкоцитах периферической крови крыс в норме и при экспериментальном сахарном диабете (ЭСД). Установлено, что исходный уровень полимеризированного актина в лейкоцитах при ЭСД достоверно выше в сравнении с контрольной группой животных, что указывает на изменение структурно-функциональных свойств и преактивированное состояние этих клеток при диабете. В лейкоцитах животных с ЭСД происходит перераспределение фракций актина, а именно - на фоне снижения общего уровня актина уменьшается количество актиновых филаментов цитоскелета, но увеличивается содержание коротких актиновых фриламентов. Полученные результаты свидетельствуют о том, что хотя исходный уровень общего актина в лейкоцитах при ЭСД снижается, сам процесс полимеризации актина интенсифицируется. Введение агматина контрольной группе животных не вызывало достоверных изменений общего содержания актина в лейкоцитах, но приводило к уменьшению количества мономеров актина в результате интенсификации полимеризации при образовании фракции коротких фриламентов. В то же время у животных с ЭСД этот полиамин способствовал повышению как общего содержания актина, так и уровня полимеризированного актина во фракции филаментов цитоскелета вследствие реорганизации (деполимеризации) коротких актиновых фриламентов. Таким образом, актин или прямо, или опосредованно влияет на функциональное состояние лейкоцитов через процессы формирования элементов цитоскелета.

Ключевые слова: актин, цитоскелет, лейкоциты, агматин, экспериментальный сахарный диабет.

Одержано: 16.09.2014

ISSN 1996-4536 (print) • ISSN 2311-0783 (on-line) • Біологічні Студії / Studia Biologica • 2014 • Том 8/№3-4 • С. 17-30 